\title{
Application of the energy audit methodology on the thermal envelope in a building for educational use in Madrid
}

\section{Aplicación de la metodología de auditoría energética sobre la envolvente térmica en un edificio de uso docente en Madrid}

\author{
Enrique Larrumbide Gómez-Rubiera (Main Author) \\ Instituto Eduardo Torroja de Ciencias de la Construcción. Consejo Superior de Investigaciones Científicas \\ Calle de Serrano Galvache, 4, 28033 Madrid (Spain) \\ elarrumbide@ietcc.csic.es
}

Jorge Gallego Sánchez-Torija (Corresponding Author)

Departamento de Construcción y Tecnología Arquitectónicas, Escuela Técnica Superior de Arquitectura, Universidad Politécnica de Madrid

Avenida de Juan de Herrera 4, 28040 Madrid (Spain)

jorge.gallego@upm.es

\section{César Bedoya Frutos}

Departamento de Construcción y Tecnología Arquitectónicas, Escuela Técnica Superior de Arquitectura, Universidad Politécnica de Madrid

Avenida de Juan de Herrera 4, 28040 Madrid (Spain)

cesar.bedoya@upm.es

Manuscript Code: 1127

Date of Acceptance/Reception: 07.02.2019/07.05.2018

DOI: 10.7764/RDLC.18.1.145

\begin{abstract}
An energy audit is a useful tool that sets out possibilities for improvement, optimization and energy saving. For the study of the thermal envelope, it is useful to use energy simulation tools that use suitably validated reference climates and simulation procedures. The results of the Unified Lider Calener Tool (HULC), and its subsequent processing of results, allow intervention priorities to be established aimed at aiding the energy manager of the building when proposing energy reform measures involving a degree of economic savings, so that the proposed investments allow a reasonable payback period. A teaching center has been chosen as a case study because presenting a tool that allows to save on energy consumption and quantify the payback terms of the investments is relevant. This paper quantifies the payback periods of the investments to be made to improve the thermal envelope of the building. To this end, the case study building was modeled and an economic analysis was carried out, which led to the conclusion that the most beneficial action is the replacement of the windows.
\end{abstract}

Keywords: energy audit, refurbishment, energy optimization, window aperture, thermal envelope.

Resumen

La auditoría energética es una herramienta útil que plantea posibilidades de mejora, optimización y ahorro de energía. Para el estudio de la envolvente térmica, es útil el uso de herramientas de simulación energética que empleen climas de referencia y procedimientos de simulación que se encuentren suficientemente validados. Los resultados que arroja la Herramienta Unificada Lider Calener (HULC), y su procesado posterior de resultados, permiten establecer prioridades de intervención que supongan una ayuda para el gestor energético del edificio a la hora proponer medidas de reforma energética que supongan un nivel de ahorro económico, de manera que las inversiones que se planteen supongan unos plazos razonables de amortizaciones. Como estudio de caso se escoge un centro docente, porque se considera que una herramienta que permita facilitar un ahorro en el consumo de energía y que cuantifique los plazos de amortización de las inversiones a realizar resulta relevante. Este documento cuantifica los períodos de retorno de las inversiones a realizar para mejorar la envolvente térmica del edificio. Para ello se modeló el edificio estudio de caso y se hizo un análisis económico que llevó a la conclusión de que lo más beneficioso es la sustitución de las ventanas.

Palabras clave: Auditoría energética, rehabilitación, optimización energética, hueco de ventana, envolvente térmica.

Introduction

Since the oil crisis of the 1970s, which gave rise to the appearance of the NBE CT-79 regulation on thermal conditions in buildings (de Gobierno, 1979), the evolution of technical energy legislation has been aimed at reducing energy consumption by reducing energy demand, an improvement in the efficiency of the facilities and the introduction of renewable energy sources. 
To solve the various issues regarding climate change and energy depletion, many countries are striving to reduce their building energy consumption, which accounts for $40 \%$ of the total energy used worldwide (Kang, 2018). Some statistics provided by the United Nations Environment Programme show that over their life cycle, buildings demand about $40 \%$ of total global energy use, $60 \%$ of global electricity, $25 \%$ of global water, $40 \%$ of all resources, and release about $1 / 3$ of global greenhouse gases (Giannetti, 2018).

Reducing energy waste and greenhouse gas emissions is an enormous challenge for the building sector, especially when considering the unsatisfactory results that have been achieved one year after the Paris Agreement (Naspi, 2018). The 2015 Paris agreement on climate change set goals and limits with the aim of reducing a further increase in global air temperatures. According to European Directives, lowering the environmental impact of buildings and improving their energy efficiency are key elements in achieving these objectives (Pajek, 2018).

The energy performance of buildings needs to be improved through measures that take into account climatic and local conditions as well as environmental characteristics (Evangelisti, 2018). Energy audits promote an improvement in energy efficiency and foster energy savings, as well as reducing greenhouse gas emissions.

The objective is the application of an energy audit on the thermal envelope of a tertiary building used for teaching in Madrid, whose analysis of energy use facilitates decision making on the reasonable investments that can be undertaken to reduce the energy bill of the building.

Although the number of studies into thermal comfort in school buildings are not comparable to those carried out in offices, a recent article (Zomorodian, 2016) reveals that 48 papers on the subject were published from 1969 to 2015 (Ricciardi, 2018).

Observational studies into the indoor climate of school classrooms have usually been justified by highlighting the adverse effects of unfavourable conditions such as warm temperatures and poor ventilation on students' comfort and academic performance (Kim, 2018).

To determine the losses and gains that occur through the thermal envelope, the Unified Lider Calener Tool "HULC" (Ministerio de Industria, Energía y Turismo, 2017), is used as a simulation program, proposing a methodology for selecting the element of the envelope which will bring about the best results from the point of view of improving energy saving.

Once the element of the envelope to be looked into is defined and the priorities for action are selected, studies into the economic investments to be made and the paybacks that are obtained from the different proposals are put forward. It then becomes possible to obtain a clear vision of the return on the different investments made.

The use of energy simulation tools and the proposed analysis methodology facilitates decision making when considering actions for the optimization and improvement of the thermal envelope, as proposed by the different methodologies that are gathered together in the respective energy audits. To select the appropriate energy analysis method, the auditor should consider several factors including speed, cost, versatility, reproducibility, sensitivity, accuracy and ease of use (Sonderegger, 1985). The most important characteristic of the simulation programs is its ability to take several parameters into account that are crucial for accurate energy use (Krarti, 2016). In the last decades, the modelling of the energy required by a building has gained an important place in the analysis of the buildings sector (Rojo, 2018).

Description of the problem

The 44\% of schools in Madrid were built before the first regulation about the thermal conditions in buildings in 1979. Another $48 \%$ of schools have been built before the current regulations that limit the energy consumption in the buildings of 2006 . Only the $8 \%$ of the schools are adapted to the current regulations whose criteria are being tightened.

This situation means that in order to maintain an adequate thermal comfort in schools, it is necessary to expend a high economic cost and a significant amount of greenhouse gases are emitted into the atmosphere, which contributes to the climate change that is intended to be mitigated. 
This research pretends to provide a tool to the managers of buildings that allow them to make an appropriate decision when facing the energy rehabilitation of the thermal envelope. The costs of this intervention are very high and the results obtained are different depending on the part of the envelope that is involved.

\section{State of the art}

The 2002/91/EC European Directive into the energy efficiency of buildings (European Parliament, 2002) does not mention energy audits.

The 2006/32/EC European Directive into the efficiency of the final use of energy and energy services (European Parliament, 2006), in point 18 of the explanatory memorandum states that "In order to achieve the potential for energy savings in certain market segments in which energy audits are generally not sold commercially, such as households, Member States should ensure the availability of energy audits". In its article, energy audits are directly addressed unlike in previous ones.

The 2010/31/EU European Directive into the energy efficiency of buildings (European Parliament, 2010) only mentions energy audits as information that can be provided to the owner of a property to which an energy efficiency certificate has been made, considered as "another related issue".

The 2012/27/EU European Directive into energy efficiency (European Parliament, 2012), in point 24 of the explanatory memorandum, states that: "Energy audits have to be obligatory and periodic for large companies, since the energy savings obtained can be significant". In its article, it directly addresses energy audits as its own content. It sets out the obligation to subject non-SME companies to an energy audit no later than December 5, 2015, and at least every four years.

The ISO (2014) 50002 standard "Energy audits -- Requirements with guidance for use" specifies the process requirements for carrying out an energy audit in relation to energy performance.

The RD 56/2016 Royal Decree, which supersedes the 2012/27/EU European Directive, indicates, among other aspects, that energy audits should reflect the detailed calculations and proposed measures, providing clear information on the potential savings.

The 2018/844/EU European Directive (European Parliament, 2018), in point 33 of the explanatory memorandum, states that: "To ensure that financial measures related to energy efficiency are applied in the best way in building renovation, they should be linked to the quality of the renovation works in light of the targeted or achieved energy savings. Those measures should therefore be linked to ... an energy audit."

The energy audit may become a fundamental tool when proposing energy intervention measures in a building which may lead to certain savings in energy consumption and, therefore, reduce $\mathrm{CO}_{2}$ emissions into the atmosphere. An energy audit attempts to allocate a value at each energy point over a given period (Moss, 2006).

The new regulatory requirements determined by Europe make it necessary to follow approaches aimed at minimizing non-renewable primary energy, as determined in the Basic Document on Energy Saving, hereinafter DB HE of 2013 (Orden FOM/1635/2013).

Windows are an influential component of the building when determining the level of energy consumption (Larrumbide, 2015 a; Omrany, 2016), which is why when proposing measures for improving the buildings, a special study must be carried out for proposing energy-saving measures in any building. Windows are responsible for wasting a significant percentage of total building energy loss of approximately $20-40 \%$ (Lee, 2013).

Energy measures should always be considered from the perspective of avoiding the later appearance of a pathology that could jeopardise the functioning of the elements of the thermal envelope due to the presence, for example, of both surface and interstitial condensations (Larrumbide, $2015 \mathrm{~b}$ ).

The Unified Tool Lider Calener (HULC) published by the Ministry of Development and the Ministry of Industry, Energy and Tourism, is a free energy distribution simulation program, which allows compliance with the regulatory requirement, the study of the energy performance of buildings and the issuing of energy certifications. 
The study is based on an existing building constructed in Madrid between 1968 and 1970, for educational use, which has not been subject to energy improvement measures.

The methodological sequence proposed for the energy audit is as follows:

- $\quad$ Collection of building data.

- Introduction of technical data into the HULC simulation program.

- $\quad$ Energy simulation of the building in its current state.

- Quantification of losses and gains through the different elements of the thermal envelope.

- $\quad$ Pre-selection of action measures based on the previous results.

- $\quad$ Simulation of possible refurbishments.

- Quantification of savings in each of the refurbishments proposed.

- Economic valuation and calculation of paybacks.

- $\quad$ Selection of final measures, based on the previous results.

The technical information of the building has been obtained 'in situ', through visual inspection and documentary review, which has been provided by the educational institution's management.

Once the technical information of the proposed building has been compiled, the geometry of the building is introduced into the simulation program used to verify the current regulatory requirement of the 2013 Technical Building Code.

Said program has been used to know the energy demand presented by each part of the thermal envelope of the building separately, both in the current state and with the modifications studied. All energy analyzes have been done with Hulc. The economic analyzes have been made using an Excel sheet.

A view of the building is shown in the Figure 1.

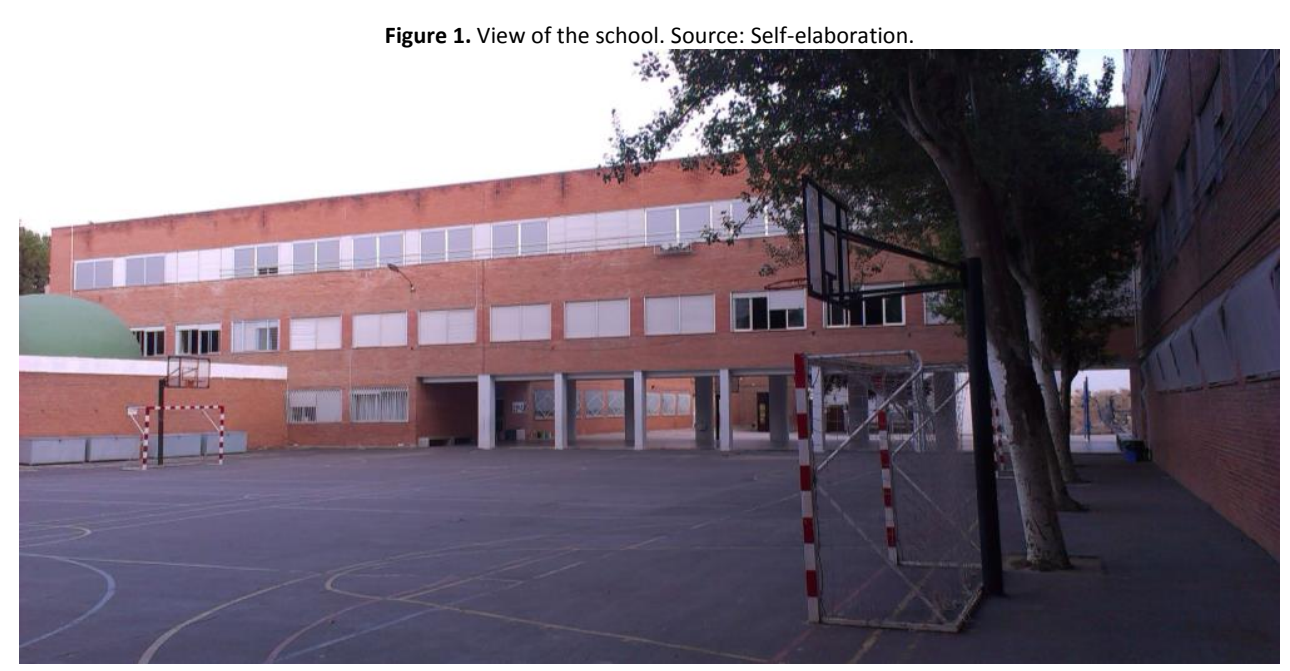

A time profile of 8 hours with an average load has been established for the calculating conditions, as referenced in appendix A of the DB HE 1 Basic Document on Energy Saving. The scenario of occupation considered is from 7:00 am to $3: 00 \mathrm{pm}$. The assigned temperatures considered are $20{ }^{\circ} \mathrm{C}$ for the winter and $25 \circ \mathrm{C}$ for the summer. The months of June, July and August have been considered non-teaching.

The internal heat sources considered correspond to the heat gains due to occupancy, lighting and computer equipment. In addition, heat gains due to solar radiation have been taken into account.

The climatic zone where the building is located is D3 and the reference climates established by regulation are used for the simulation. The reference climate contemplates an average temperature of $4.9^{\circ} \mathrm{C}$ in January and $24.5^{\circ} \mathrm{C}$ in August. The annual heating degree days that have been considered are 2,693 and the annual cooling degree days are 491. 
As a reference, the maximum and minimum hourly temperatures that occur during the year considered for the calculation, as well as the assigned temperatures established in accordance with the regulations in force, are detailed in Figure 2.

Figure 2. Annual maximum and minimum outside temperatures. Source: Self-elaboration.

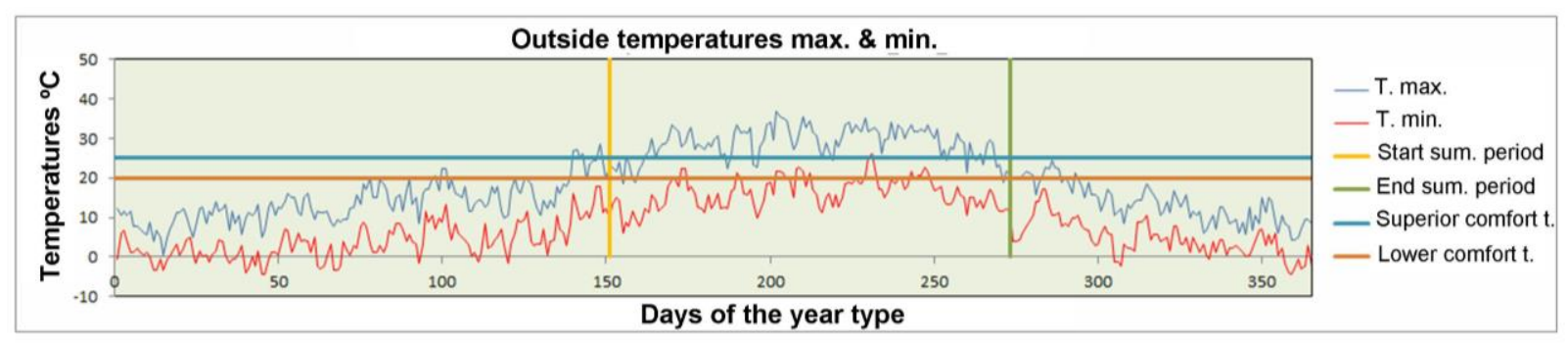

The results of the heating and cooling demand are obtained on a monthly basis, as can be seen in Figure 3 , which reflects the monthly heating and cooling demands for the selected building.

The possible actions that can be carried out on the thermal envelope to improve the thermal behaviour of the building may be the replacement of the existing glazed recesses, the provision of thermal insulation on the facade, on the roof, on the external slabs or in the envelopes in contact with the ground and an improvement in the thermal bridges. In the case analyzed herein, the associated effect of improvement in thermal bridges has not been considered in all of the proposed actions.

In order to have a better understanding of the energy performance of the building, it is necessary to quantify the thermal losses and gains that take place through the different elements that make up the thermal envelope, as indicated graphically in Figure 3. In this sense, the simulation tool used (HULC) yields results of the net energy balance through elements which offer valuable information to guide the designer when proposing energy-reform actions.

The possible actions include those measures that affect the teaching activity least such as the replacement of windows and the provision of thermal insulation on the outside, both on the roof and facade.

Through the analysis of the thermal gains and losses that occur through the different elements of the thermal envelope, the most sensitive points of the envelope are determined to see where the greater energy losses occur and, therefore, may be improved through refurbishments. In the model used for the existing building, it can be seen how the greatest losses in heating take place through glazed recesses, although it is also this element that contributes the most to the contribution of energy capture through solar collection. The next element that could be improved is ventilation, followed by an improvement in the facade, thermal bridges, roof and floor.

Once the initial sequence of action has been selected, a comparison is proposed between the improvement in the glazed recesses, the insulation from the exterior and an improvement in insulation on the roof.

Once the refurbishments have been determined, simulations are again carried out to quantify the savings that can be obtained in each of the actions proposed. It is essential to detect the areas for improvement and evaluate their influence on the final energy consumption of the building (García, 2010).

In order to calculate the savings obtained, the existing facilities of the building as well as current fuel prices are maintained. The analysis is limited exclusively to the elements of the thermal envelope.

Finally, the investments that are required for the different actions considered are established, setting out the payback periods for each proposal made, offering detailed financial information to the educational center that facilitates the decision making on reasonable investments.

As simplifications that have been made in the analysis, maintenance costs and replacement costs that entail the refurbishments considered have not been taken into account. 


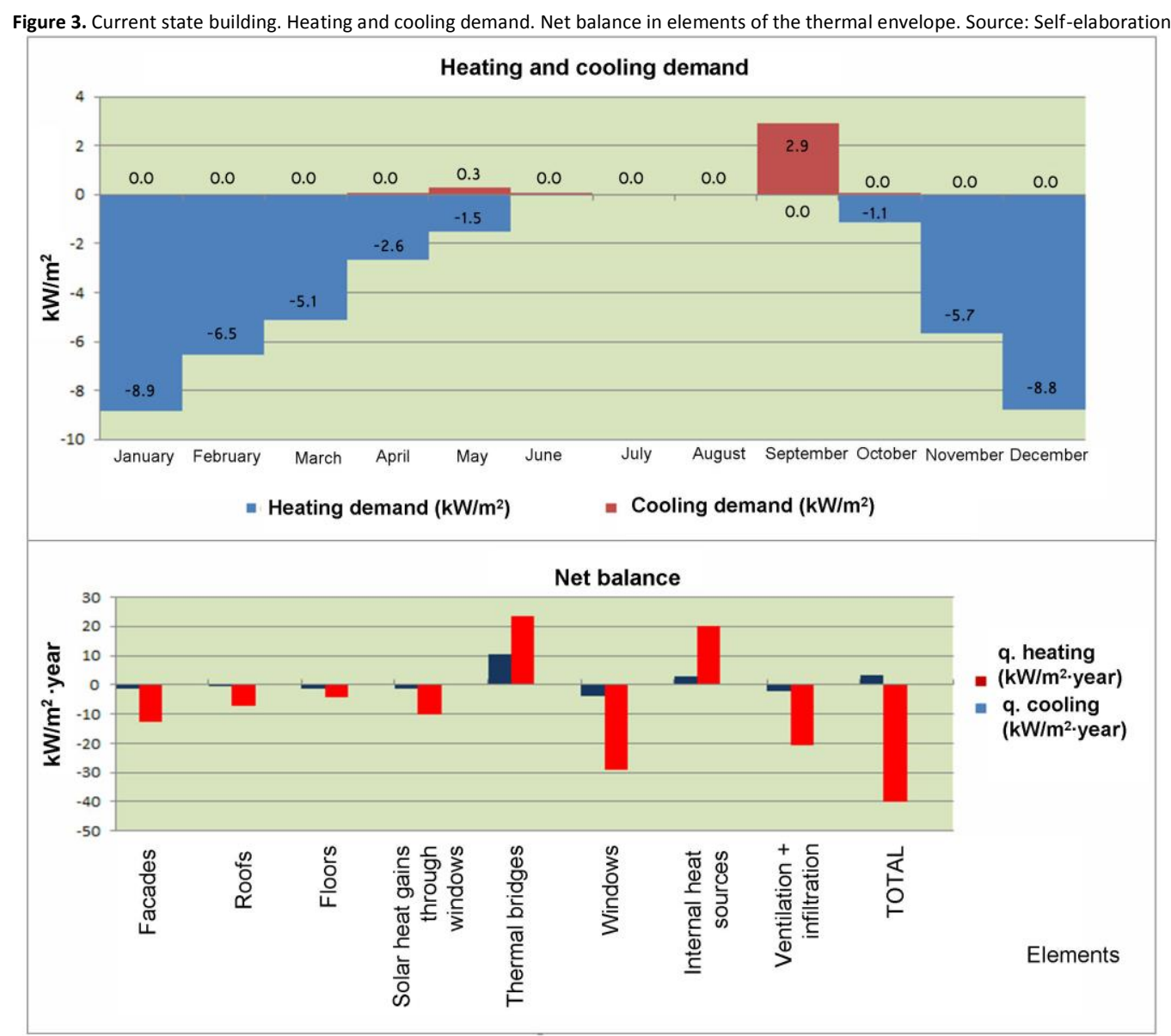

\section{Considered data}

The building is perfectly aligned along the north-south axis. It faces all four points of the compass.

The building has a living area of $7,404.37 \mathrm{~m}^{2}$, a volume of $19,671.09 \mathrm{~m}^{3}$ and a compactness of $1.97 \mathrm{~m}^{3} / \mathrm{m}^{2}$.

The total area of glazed recesses is $985.2 \mathrm{~m}^{2}$, which represents a total of $9.87 \%$ of the thermal envelope. The opaque envelope accounts for $39.67 \%$ of the envelope, the roof of $25.35 \%$, the external floor of $2.76 \%$ and the floor in contact with the ground $22.36 \%$ of the total.

The thermal transmittances of the elements of the envelope of the current state and successive refurbishments that have been proposed are shown in Table 1.

Table 1. Thermal transmissions of the elements of the thermal envelope in the current state (EA) and different proposed reforms.
\begin{tabular}{llllll}
\hline Source: Self-elaboration. & R2 & R3 \\
\hline Constructive element & EA & R1 & R2 & Thermal transmittances $\left(\mathrm{W} / \mathrm{m}^{2} \cdot \mathrm{K}\right)$ \\
\hline Roof & & 0.65 & 0.65 & 0.32 \\
Facade & 0.65 & 0.60 & 0.32 & 0.60 \\
Floor & 0.60 & 2.45 & 2.45 & 2.45 \\
External slab & 2.45 & 1.91 & 1.91 & 1.91 \\
Glass & 1.91 & 1.60 & 5.70 & 5.70 \\
Frame & 5.70 & 2.20 & 5.70 & 5.70 \\
Average value of window & 5.70 & 1.66 & 5.70 & 5.70 \\
\hline
\end{tabular}


In which,

R1: It is the refurbishment of the windows

$\mathrm{R} 2$ : It is the refurbishment consisting of the provision of thermal insulation on the outside of the facade.

R3: It is the refurbishment consisting of the addition of thermal insulation on the roof.

A thermal transmittance of the frames for the new windows proposed has been selected as very low to avoid the risk of surface condensation.

The intervention prices that have been used for the planned refurbishments are those detailed in Table 2, obtained from the construction price generator CYPE engineer of 2017.

Table 2. Prices of the refurbishment. Source: Construction price generator
\begin{tabular}{lc}
\multicolumn{2}{c}{ CYPE Engineer 2017. } \\
\hline Refurbishment prices & $€ / \mathrm{m}^{2}$ \\
\hline Replacement of frames & 279.40 \\
External Insulation & 74.80 \\
Insulation on deck & 71.13 \\
\hline
\end{tabular}

The costs of demolition or replacement, scaffolding and new construction solutions are included in these prices.

For the estimation of the final energy consumption for heating, the existence of a diesel boiler with a yield of $70 \%$ and an energy cost of $0.0848 € / \mathrm{kW}$ has been considered.

The results of the analysis of the existing building, according to the proposed methodology are shown below. They detail both the building without refurbishments or its current status, and after the window refurbishments, which is the action proposal with the best results.

\section{Without refurbishments or current status}

In Table 3, we can see how the demand for heating in this case is $40.18 \mathrm{~kW} \cdot \mathrm{h} / \mathrm{m}^{2} \cdot$ year. As regards the window openings, it can be seen how the transmission losses through the windows are very high, reaching 29.02 $\mathrm{kW} \cdot \mathrm{h} / \mathrm{m}^{2}$.year. Profits per gap have been quantified as $23.32 \mathrm{~kW} \cdot \mathrm{h} / \mathrm{m}^{2}$.year. This indicates that there is a deficit in the annual energy balance for this constructive element, due to the high thermal transmittances of the aforementioned gaps.

\begin{tabular}{lcccccc}
\multicolumn{6}{c}{ Table 3. Demand for heating and cooling by elements. Current state of the building. Detailed calculation. Source: Self-elaboration. } \\
\hline & $\begin{array}{c}\text { Heat_(+) } \\
\left(\mathrm{kWh} / \mathrm{m}^{2}\right)\end{array}$ & $\begin{array}{c}\text { Heat_(-) } \\
\left(\mathrm{kWh} / \mathrm{m}^{2}\right)\end{array}$ & $\begin{array}{c}\text { Dheat_net } \\
\left(\mathrm{kWh} / \mathrm{m}^{2}\right)\end{array}$ & $\begin{array}{c}\text { Cool_(+) } \\
\left(\mathrm{kWh} / \mathrm{m}^{2}\right)\end{array}$ & $\begin{array}{c}\text { Cool_(-) } \\
\left(\mathrm{kWh} / \mathrm{m}^{2}\right)\end{array}$ & $\begin{array}{c}\text { Dcool_net } \\
\left(\mathrm{kWh} / \mathrm{m}^{2}\right)\end{array}$ \\
\hline Facades & 0.01 & -12.51 & -12.50 & 0.15 & -1.60 & -1.45 \\
Roofs & 0.02 & -7.13 & -7.11 & 0.20 & -0.52 & -0.32 \\
Floors & 0.00 & -4.32 & -4.31 & 0.03 & -1.26 & -1.22 \\
Thermal bridges & 0.01 & -10.02 & -10.02 & 0.16 & -1.66 & -1.50 \\
Solar windows & 23.32 & 0.00 & 23.32 & 10.41 & 0.00 & 10.41 \\
Windows & 0.00 & -29.02 & -29.02 & 0.24 & -4.02 & -3.78 \\
Internals sources & 20.11 & 0.00 & 20.11 & 2.99 & 0.00 & 2.99 \\
Ventilation \& infiltration & 0.01 & -20.65 & -20.64 & 0.09 & -2.09 & -2.00 \\
\hline Total & 43.48 & -83.66 & -40.18 & 14.27 & -11.14 & 3.13 \\
\hline
\end{tabular}

Another way of facilitating a decision on the weakest element of the thermal envelope is to observe Figure 4, which shows that, once the percentage of gains and losses of heating through the elements of the envelope has been determined thermally, the most interesting refurbishment, from the energy point of view in the heating period would be to reduce heat transmission through the windows, which represents $34.7 \%$ of the energy losses of the whole building for the heating period. The next improvement to the envelope would be to refurbish the facade, which 
represents $15 \%$ of the losses, and finally the performance of the roof, which reaches $8.5 \%$, would initially be the least interesting.

Figure 4. Percentage of gains and losses in heating through the constituent elements of the thermal envelope. Source: Self-elaboration.

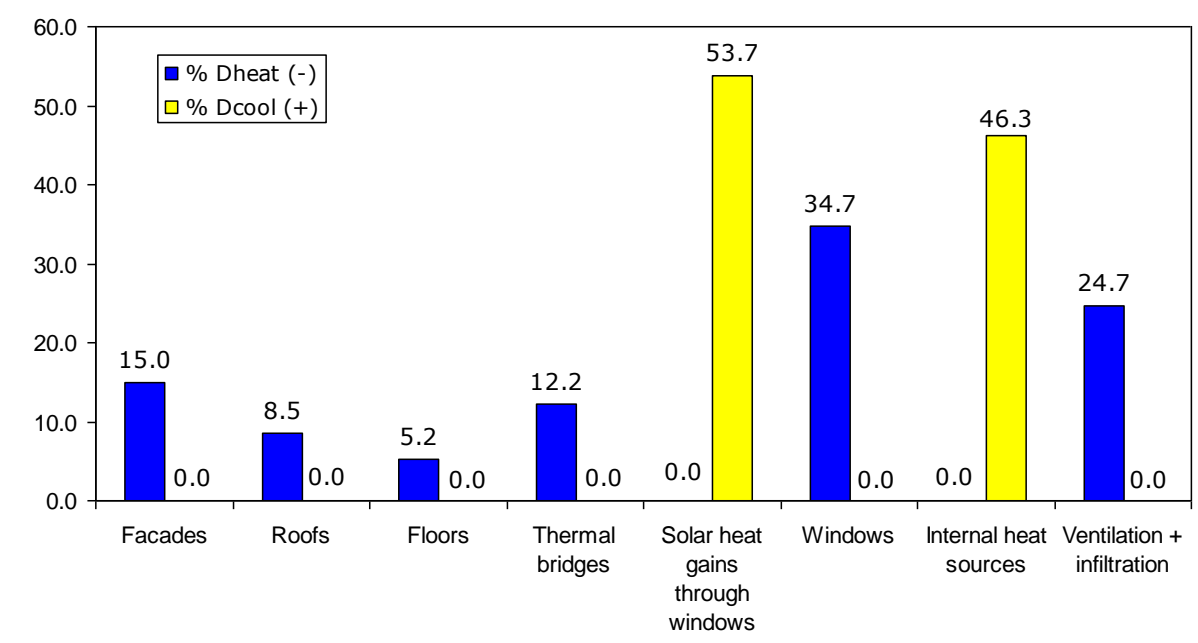

In the same way, possible refurbishments for the cooling period may be analyzed.

\section{Building with refurbishments to the window}

In the building with refurbishments to the window, the results of the demand for heating and cooling for the different months of the year, together with the data on energy gains and losses, in $\mathrm{kW} \cdot \mathrm{h} / \mathrm{m}^{2}$.year, for the elements that make up the thermal envelope are detailed in Figure 5.

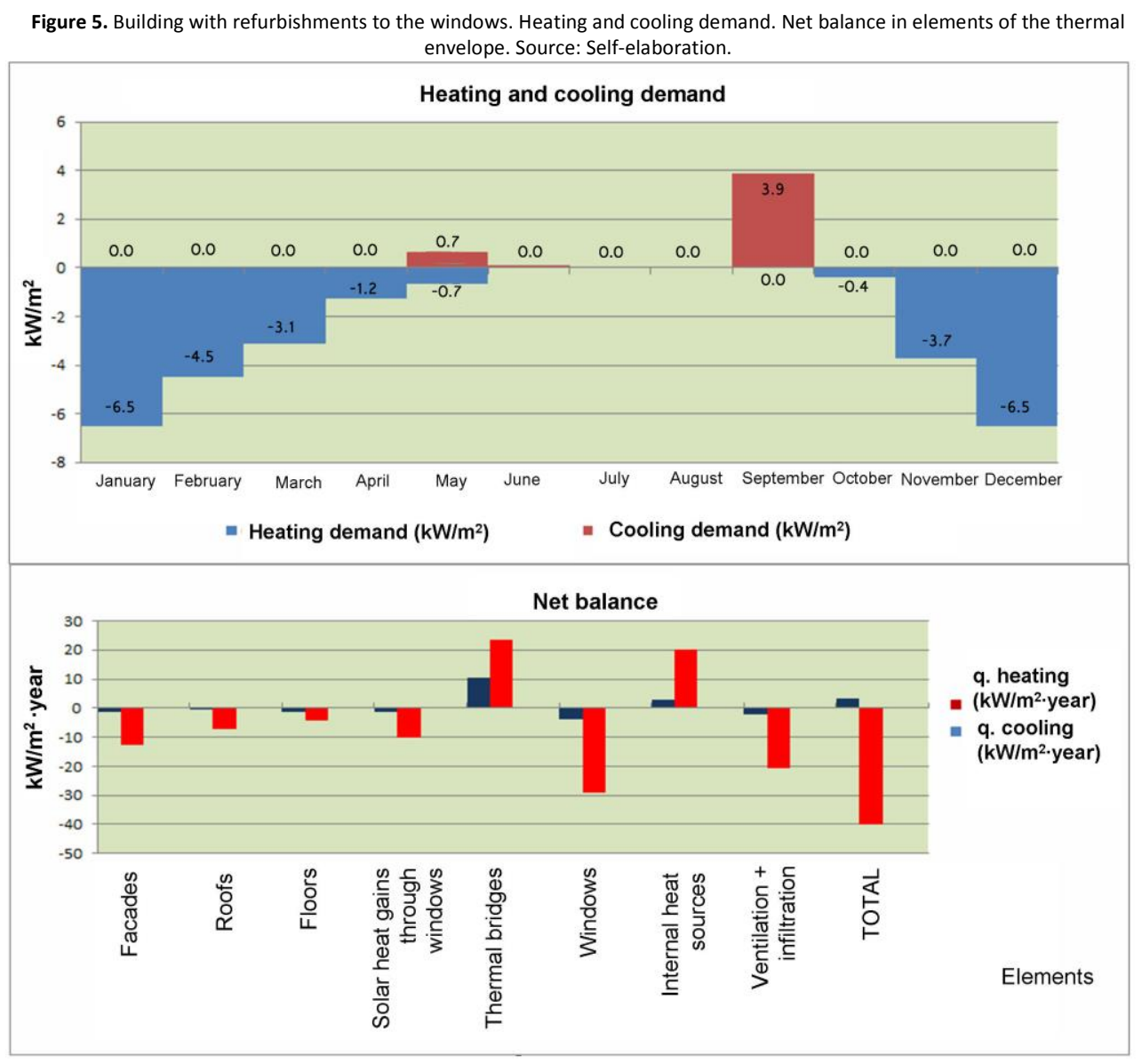


The calculations for this case are detailed in Table 4.

\begin{tabular}{lcccccc} 
Table 4. Demand for heating and cooling by elements. Building with refurbishments to the window openings. Detailed calculation. Source: Self-elaboration \\
\hline & $\begin{array}{c}\text { Heat_(+) } \\
\left(\mathrm{kWh} / \mathrm{m}^{2}\right)\end{array}$ & $\begin{array}{c}\text { Heat_(-) } \\
\left(\mathrm{kWh} / \mathrm{m}^{2}\right)\end{array}$ & $\begin{array}{c}\text { Dheat_net } \\
\left(\mathrm{kWh} / \mathrm{m}^{2}\right)\end{array}$ & $\begin{array}{c}\text { Cool_(+) } \\
\left(\mathrm{kWh} / \mathrm{m}^{2}\right)\end{array}$ & $\begin{array}{c}\text { Cool_(-) } \\
\left(\mathrm{kWh} / \mathrm{m}^{2}\right)\end{array}$ & $\begin{array}{c}\text { Dcool_net } \\
\left(\mathrm{kWh} / \mathrm{m}^{2}\right)\end{array}$ \\
\hline Facades & 0.01 & -14.18 & -14.16 & 0.29 & -2.62 & -2.33 \\
Roofs & 0.01 & -7.82 & -7.81 & 0.27 & -0.78 & -0.51 \\
Floors & 0.00 & -4.63 & -4.63 & 0.08 & -1.52 & -1.44 \\
Thermal bridges & 0.01 & -10.20 & -10.19 & 0.33 & -2.25 & -1.92 \\
Solar windows & 17.25 & 0.00 & 17.25 & 11.55 & 0.00 & 11.55 \\
Transmission wind. & 0.04 & -7.39 & -7.35 & 0.57 & -2.55 & -1.99 \\
Internals sources & 20.00 & 0.00 & 20.00 & 4.45 & 0.00 & 4.45 \\
Ventilation \& & 0.01 & -19.77 & -19.76 & 0.09 & -3.27 & -3.18 \\
infiltration & 37.33 & -63.99 & -26.65 & 17.63 & -13.00 & 4.63 \\
\hline Total & & & & & &
\end{tabular}

In summary, the savings and paybacks for the heating period that have been obtained in each of the proposed refurbishments are detailed in Table 5.

\begin{tabular}{|c|c|c|c|c|}
\hline \multirow{2}{*}{$\begin{array}{l}\text { Elements } \\
\text { Interventions }\end{array}$} & \multicolumn{4}{|c|}{ Dcal_net $\left(\mathrm{kWh} / \mathrm{m}^{2}\right)$} \\
\hline & Actual state & R_window & R_facade & $R_{\text {_roof }}$ \\
\hline Facades & -12.50 & -14.16 & -6.56 & -12.75 \\
\hline Roofs & -7.11 & -7.81 & -7.47 & -3.89 \\
\hline Floors & -4.31 & -4.63 & -4.51 & -4.31 \\
\hline Thermal bridges & -10.02 & -10.19 & -10.49 & -10.25 \\
\hline Solar windows & 23.32 & 17.25 & 23.34 & 23.38 \\
\hline Transmission windows & -29.02 & -7.35 & -30.47 & -29.52 \\
\hline Internal sources & 20.11 & 20.00 & 20.24 & 20.19 \\
\hline Ventilation \& Infiltration & -20.64 & -19.76 & -20.80 & -20.70 \\
\hline TOTAL & -40.18 & -26.65 & -36.71 & -37.85 \\
\hline Saving $\left(\mathrm{kWh} / \mathrm{año} \cdot \mathrm{m}^{2}\right)$ & & 13.53 & 3.47 & 2.33 \\
\hline Saving (kWh/año) & & $100,181.13$ & $25,693.16$ & $17,252.18$ \\
\hline Saving (\%) & & 33.67 & 8.64 & 5.80 \\
\hline \multicolumn{5}{|c|}{ Costs, yields and paybacks } \\
\hline Costs $\left(€ / \mathrm{m}^{2}\right.$ element $)$ & & 279.40 & 74.80 & 71.13 \\
\hline $\mathrm{m}^{2}$ element & & 985.20 & $3,960.31$ & $2,531.52$ \\
\hline Total investment(€) & & $275,264.88$ & $296,231.19$ & $180,067.02$ \\
\hline Costs ( $€ / \mathrm{m}^{2}$ useful surface) & & 37.18 & 40.01 & 24.32 \\
\hline Yield of the system (\%) & 70 & 70 & 70 & 70 \\
\hline $\begin{array}{l}\text { Consumption without } \\
\text { saving }(€)\end{array}$ & & $143,115.89$ & $36,704.52$ & $24,645.97$ \\
\hline Enery costs $(€ / k W)$ & & 0.0848 & 0.0848 & 0.0848 \\
\hline $\begin{array}{l}\text { Annual energy savings } \\
\text { (€/year) }\end{array}$ & & $12,136.23$ & $3,112.54$ & $2,089.98$ \\
\hline Amortization (years) & & 22.7 & 95.2 & 86.2 \\
\hline
\end{tabular}

It can be clearly seen how the lowest payback periods are reached with refurbishments to the window openings, with a payback period of 22.7 years. 
The energy audit analysis carried out on the thermal envelope in a teaching center located in Madrid, concludes that the best refurbishment that can be proposed is that with which the greatest energy savings are obtained and paid back in the shortest possible time. In this case, it is clear that the refurbishments to the facade and roof are not profitable due to the long payback period, both close to 100 years.

According to the initial thermal analysis, the most interesting operation was to refurbish the windows first, secondly the facades and finally the roof. Once introduced the economic study the sequence of proposed refurbishments would be to invest in the windows, followed by the facade.

For this type of building which is usually in use for around 8 hours and without teaching during June, July and August, it has about 1,728 hours of annual operation, so that the possibilities of saving energy are somewhat more limited than in buildings with the same characteristics with a greater number of hours of teaching use. On the other hand, the payback periods, which are so high for the facade and roof operations, are due to the fact that the levels of insulation found in the existing building are high, which is why it is not profitable for the centre to undertake the investment on these constituent elements of the thermal envelope.

When carrying out energy audits and estimating the possible optimization of energy demand through the thermal envelope and proposing certain energy savings to the energy manager of the building, it is useful to use an officially recognized energy analysis tool with which they can be used, for example, to calculate the annual energy balance on a complex element, such as gaps in windows, in which thermal losses and solar gains occur; or, although it has not been considered in the study, the evaluation of energy losses through thermal bridges. The use of other energy audit methodologies does not consider the effect of thermal bridges due to the difficulty in quantifying their contribution to the energy losses of the building complex.

This analysis methodology allows the most accurate information on the best energy reform refurbishments that can be presented in a unit to be obtained, in this case, a teacher, advising the center's management on the suitable investments that can be made.

The results obtained will allow monitoring or more detailed studies that are obtained to be compared with subsequent studies 'in situ' on the real invoices of final energy consumption.

The results obtained are valid for the use of the building and for the climate where the case study was carried out. So the conclusions obtained are not valid for other uses or for other climates. However, the described analysis methodology can be applied to buildings with other uses and in other climates and it permits obtain the corresponding results for each case.

Evangelisti, L., Guattari, C., Gori, P., \& Asdrubali, F. (2018). Assessment of equivalent thermal properties of multilayer building walls coupling simulations and experimental measurements. Building and Environment, 127, 77-85. https://doi.org/10.1016/j.buildenv.2017.10.038

De Gobierno, P. (1979). Real Decreto 2429/1979, de 6 de julio, por el que se aprueba la norma básica de edificación NBE-CT-79, sobre condiciones térmicas en los edificios. Boletín Oficial del Estado, (253), 24524-24550.

European Parliament (2002). Directive 2002/91/EC of the European Parliament and of the Council of 16 December 2002 on the energy performance of buildings. Official Journal of the European Communities. January 4, 2003, Vol. 46, pp. 65-71.

European Parliament (2006). Directive 2006/32/EC of the European Parliament and of the Council of 5 April 2006 on energy end-use efficiency and energy services and repealing Council Directive 93/76/EEC. Official Journal of the European Communities. April 27, 2016, Vol. 49, pp. 64-85.

European Parliament (2010). Directive 2010/31/EU of the European Parliament and of the Council of 19 May 2010 on the energy performance of buildings. Official Journal of the European Communities. June 18, 2010, Vol. 53, pp. 13-23.

European Parliament (2012). Directive 2012/27/EU of the European Parliament and of the Council of 25 October 2012 on energy efficiency, amending Directives 2009/125/EC and 2010/30/EU and repealing Directives 2004/8/EC and 2006/32/EC. Official Journal of the European Communities. November 14, 2012, Vol. 55, pp. 1-56.

European Parliament (2018). Directive (EU) 2018/844 of the European Parliament and of the Council of 30 May 2018 amending Directive 2010/31/EU on the energy performance of buildings and Directive 2012/27/EU on energy efficiency. Official Journal of the European Communities. June 19, 2018, Vol. 61, pp. 75-91. 
Giannetti, B. F., Demétrio, J. C., Agostinho, F., Almeida, C. M., \& Liu, G. (2018). Towards more sustainable social housing projects: Recognizing the importance of using local resources. Building and Environment, 127, 187-203. https://doi.org/10.1016/j.buildenv.2017.10.033

International Organization for Standardization. (2014). Energy audits - Requirements with guidance for use (ISO Standard No. 5002). Retrieved from: https://www.iso.org/obp/ui/\#iso:std:iso:50002:ed-1:v1:en

Kang, H., Lee, M., Hong, T., \& Choi, J. K. (2018). Determining the optimal occupancy density for reducing the energy consumption of public office buildings: A statistical approach. Building and Environment, 127, 173-186. https://dx.doi.org/ 10.1016/j.buildenv.2017.11.010

Kim, J., \& de Dear, R. (2018). Thermal comfort expectations and adaptive behavioural characteristics of primary and secondary school students. Building and Environment, 127, 13-22. https://doi.org/10.1016/j.buildenv.2017.10.031

Krarti, M. (2016). Energy audit of building systems: an engineering approach. Boca Raton: CRC press.

Larrumbide Gómez-Rubiera, E., \& Bedoya Frutos, C. (2015 a). El comportamiento del hueco de ventana en la arquitectura vernácula mediterránea española ante las necesidades de acondicionamiento solar. Informes de la Construcción, 67(539), 120-130. http://dx.doi.org/10.3989/ic.14.056.

Larrumbide, E. (2015 b). Patologías asociadas a la rehabilitación energética: comportamiento higrotérmico. Conarquitectura 53 , 76 - 81.

Lee, J. W., Jung, H. J., Park, J. Y., Lee, J. B., \& Yoon, Y. (2013). Optimization of building window system in Asian regions by analyzing solar heat gain and daylighting elements. Renewable energy, 50, 522-531. https://doi.org/10.1016/j.renene.2012.07.029

Ministerio de Industria, Energía y Turismo \& IDAE (2017) Herramienta Unificada LIDER-CALENER (HULC), Herramienta informática de verificación de la exigencia de Limitación de demanda energética del CTE.

Moss, K. J. (2006). Energy management in Buildings. New York: Taylor \& Francis.

Naspi, F., Arnesano, M., Zampetti, L., Stazi, F., Revel, G. M., \& D'Orazio, M. (2018). Experimental study on occupants' interaction with windows and lights in Mediterranean offices during the non-heating season. Building and Environment, 127, 221-238. https://doi.org/10.1016/j.buildenv.2017.11.009

Omrany, H., \& Marsono, A. K. (2016). Optimization of building energy performance through passive design strategies. British Journal of Applied Science \& Technology, 13(6), 1-16. https://www.doi.org/10.9734/BJAST/2016/23116

Orden FOM/1635/2013, de 10 de septiembre, por la que se actualiza el Documento Básico DB-HE "Ahorro de Energía», del Código Técnico de la Edificación, aprobado por Real Decreto 314/2006, de 17 de marzo. Boletín Oficial del Estado. Madrid, September 12, 2013, Vol. 219, pp. 67137-67209.

Pajek, L., \& Košir, M. (2018). Implications of present and upcoming changes in bioclimatic potential for energy performance of residential buildings. Building and Environment, 127, 157-172. https://doi.org/10.1016/j.buildenv.2017.10.040

Real Decreto 56/2016, de 12 de febrero, por el que se transpone la Directiva 2012/27/UE del Parlamento Europeo y del Consejo, de 25 de octubre de 2012, relativa a la eficiencia energética, en lo referente a auditorías energéticas, acreditación de proveedores de servicios y auditores energéticos y promoción de la eficiencia del suministro de energía. Boletín Oficial del Estado. Madrid, July 31, 2016, Vol. 182, pp. 2978129783.

Ricciardi, P., \& Buratti, C. (2018). Environmental quality of university classrooms: Subjective and objective evaluation of the thermal, acoustic, and lighting comfort conditions. Building and Environment, 127, 23-36. https://doi.org/10.1016/j.buildenv.2017.10.030

Rojo, C., Fissore, A., \& De Herde, A. (2018). The difference between theoretical and measured energy consumption in residential heating: Chilean case. Revista de la Construcción. Journal of Construction, 17(1), 149-157. http://doi.org/10.7764/RDLC.17.1.149

Sonderegger, R. C. (1985). Thermal modeling of buildings as a design tool. Proceedings of CHMA $2000,1$.

Zomorodian, Z. S., Tahsildoost, M., \& Hafezi, M. (2016). Thermal comfort in educational buildings: A review article. Renewable and sustainable energy reviews, 59, 895-906. https://doi.org/10.1016/j.rser.2016.01.033 